\title{
Lo que no aprendí: el arte de tejer una ficción de autora (Ejercicio fictocrítico \#3)*
}

Fecha de recepción: 02 de febrero de 2017

Fecha de aprobación: 27 de junio de 2017

\section{Resumen}

Este ejercicio fictocrítico analiza la novela de la escritora Margarita García Robayo Lo que no aprendí (2014). Este diálogo se propone explicar cómo la novela de la colombiana funciona como una autoficción y como para ello hace uso de la "ficción de autor", concepto de Julio Premat, para construir dentro de la misma obra un concepto de escritora, narradora y autora.

Palabras clave: Margarita García Robayo, novela colombiana, autoficción, ficción de autor, fictocrítica.

Citar: Castillo Rojo, C. (enero-junio de 2017). Lo que no aprendí: el arte de tejer una ficción de autora. (Ejercicio fictocrítico \#3). La Palabra, (30), 115 - 129. doi: https://doi.org/10.19053/01218530.n30.2017.6333

\section{Camilo Castillo Rojo}

Escritor y Ph.D. Candidate de Hispanic Studies, University of British Columbia. MFA en Creación Literaria de la University of Texas at El Paso (2009). camilocastillorojo@gmail.com

*"Fictocriticism is one practice which enables the interrogation and the shifting of the boundaries of the essay (or any other genre). As I have suggested, in defamiliarising genre, fictocriticism interrogates the way in which academic knowledges are constructed. It can be seen as a 'space-clearing' strategy which enables dialogisation, the hybridisation and relativisation of knowledges". Anne Brewster en "Fictocriticism: undisciplined writing" (p. 31). 


\section{la palabra}

[What I Didn't Learn]: The Art of Weaving a (Female) Authorial Fiction. (Fictocritical Exercise \#3)

\section{Abstract}

This fictocritical exercise analyzes the novel of the writer Margarita García Robayo Lo que no aprendi [What I didn't learn] (2014). This dialogue attempts to explain the autofictional functioning of this Colombian novel and its use of "authorial fiction", a theory by Julio Premat, in order to construct within the novel a concept of writer, narrator and author.

Keywords: Margarita García Robayo, Colombian novel, Autofiction, Authorial fiction, fictocriticism

\section{Lo que no aprendí: [Ce que je n'ai/pas appris] l'art de construire une fiction de femme écrivain (Exercice fiction-critique 1 \# 3)}

\section{Resumé}

Cet exercice fictocritique analyse le roman de l'écrivain Margarita García Robayo Lo que no aprendí (2014). Nous étudierons dans quelle mesure ce roman fonctionne comme une autofiction et de quelle manière celle-ci est construite à partir de l'utilisation du concept de Julio Premat "la fiction d'auteur". Ainsi, Robayo construit dans son oeuvre un concept d'écrivain, de nageuse et auteur.

Mots-clés: Margarita García Robayo, roman colombien, autofiction, fiction d'auteur, ficcion-critique. 


\section{Sólo obtienes algo de los libros si eres capaz}

de poner algo tuyo en lo que estás leyendo.

Sándor Márai

Saco la novela de la maleta, dejándola en el bolsillo del puesto de enfrente, junto a la revista de la aerolínea $\mathrm{y}$ el inmaculado volante de instrucciones de emergencia. El libro para mis hijos lo dejo dentro de la bolsa de la librería, en el mismo bolsillo del portátil. Violeta se saca los zapatos, se acomoda en sentado indio, se abrocha el cinturón y mira por la ventanilla mientras agarra su cabello en una coleta. Hace calor. Regresamos cansados y felices. Mas, cada uno volverá a su casa, a su "realidad". Yo espero pasar unos días con mis hijos, escribir el artículo. Ella regresa a su novela, es escritora: renunció a la academia para dedicarse a escribir, y por eso todavía vive en casa de su madre. No está segura de si debe irse a vivir conmigo, su ex-profesor cuasi divorciado y padre de dos niños. Es complicado.

Por suerte, pudimos escapar a México. Qué lindo país. $\mathrm{Su}$ gente, sus pirámides. Mis carnalitos nos recibieron $\mathrm{y}$ alimentaron con cariño. Elamigo de Violeta, uno de los miles de colombianos en el país azteca, un rolo amable y querido, nos invitó mezcal y conversaciones hasta la madrugada. Una tarde, en la plaza de mercado de Xochimilco, cuando comíamos en silencio quesadillas de flor de calabaza, nos miramos. Violeta estaba alegre, yo me sentía feliz. Acaso por ese instante nos convertimos en la pareja del cuento de Calvino, unos turistas que se redescubren gracias al gusto por la comida mexicana. No sé. Quizás, en el futuro, pueda ser uno de aquellos escritores colombianos expatriados que hacen su obra fuera, acaso algún día no muy lejano pueda venir a vivir y a dedicarme a escribir, y como muchos escritores logre una carrera fuera del país. Tal vez Violeta quiera hacerse escritora fuera de Colombia y me traiga consigo. Aunque, bueno, ¿qué afán?, estoy delirando, apenas es nuestro primer viaje juntos fuera del país, para qué hacer planes tan pronto. Además, están los niños. Si me voy de Colombia, va a ser más difícil verlos.

Estuvo bien el viaje, digo, no somos perita en dulce: soy un obsesivo delirante, ella una terca furibunda. Ella es curiosa, se desenvuelve con la tecnología $\mathrm{y}$ el internet con ligereza, mientras yo apenas puedo con el correo electrónico. Tiene ese don de gente que abre puertas, genera sonrisas y amabilidad donde sea. Es reflexiva, analítica. Yo me oriento fácil y comprendo rápido el transporte y la lógica cambiaria, me encantan los mapas y moverme sobre ellos, pero soy pésimo regateador y me venden todo al doble. Violeta, por fortuna, se apropia de su rol de compradora $\mathrm{y}$ negocia hasta un botón, $\mathrm{y}$ me deja a mí un estudiado rol del "hombre del dinero" que saca los billetes del bolsillo solo cuando ella ha logrado un buen descuento. A veces ella parece estar sumergida en su melancolía, pero, a veces, es ella quien me baja de mi nube de ego. Nos la llevamos bien.

Además, compartimos lecturas. Lo último que leímos juntos es Lo que no aprendí (2014) de Margarita García Robayo. Mientras elavión caminala pista, sacó la novela del bolsillo del espaldar del puesto de enfrente y releo. Es una novela extraña, inquietante. Está dividida en dos partes. La parte inicial, es narrada en primera persona por una niña cartagenera de once años, Catalina, quien relata sus vacaciones entre junio y julio de 1991. Con un estilo sencillo, directo y con diálogos punzantes. retrata a su familia costeña arribista, una clase media deseando ser gringa. Asimismo, con gran sutileza, la narradora permite entrever una época clave de nuestro 
país: se escribe la Constitución Nacional y Pablo Escobar se entrega para pasar una corta temporada en la mal llamada cárcel "La Catedral".

Bajo ese fondo político $\mathrm{y}$ social, la historia devela la presencia de tres figuras que marcan el fin de la infancia de Catalina. La primera es la de Aníbal, un jipi mariguanero vende manillas, quien surge como una presencia seductora, intensa, y con quien Catalina tendrá un breve episodio confuso, entre romántico y abusivo. La segunda es la de la madre, mujer cantaletosa, súper arribista, de un dramatismo atroz y quien regaña, cuestiona y teme por su hija. La tercera es la figura de su padre, un hombre mayor, abogado pensionado $\mathrm{y}$ alejado de las cuitas cotidianas, sumergido en sus tareas benefactoras, sus búsquedas esotéricas y en sus lecturas.

La segunda parte, escrita en un estilo menos parco $\mathrm{y}$ mucho más reflexivo, funciona como un enclave para releer y completar la primera parte. En esta, una mujer cartagenera, radicada en Buenos Aires, y quien se empieza a labrar una carrera como escritora, cuenta la muerte de su padre, abogado pensionado y sumergido en sus búsquedas espirituales, igual al papá de Catalina, en la primera parte. Esa muerte hunde a la escritora en un arduo proceso emocional que se arremolina al extremo con la visita de su madre, una mujer cantaletosa e imponente, la madre de la primera parte, y ante ese sisma familiar, la mujer decide escribir sobre su infancia, sobre la figura de su padre y su relación con él. La escritora, además, desnuda cómo se elabora su escrito: añade varios elementos de ficción (se intuye que se trata de la historia de Aníbal) para completar sus recuerdos y así armar un argumento sólido. Por supuesto, esta segunda parte se trata del proceso de escritura de la primera parte de Lo que no aprendí. Es decir que esta segunda sección, deconstruye y analiza la primera parte, esa aparente novela tradicional, de orden meramente ficcional sobre el tema de la memoria relatada desde la infancia, y redefine la novela con un carácter metaficcional.

—QQué te pareció? -le pregunto a Violeta.

—QQué? - pregunta mirando el estático asfalto de la pista.

- La novela.

-Me gustó. Es como autobiográfica, ¿no? —dice, mirando la niña de la portada.

- Me parece que es más cercana a la autoficción. — ¿Seguro? ¿Autoficción? -Puede ser. Mira, hay un crítico español, Manuel Alberca (2012) que dice que una clave de la novela autobiográfica es que "se perciban la historia y sus protagonistas o los personajes de esta, como una proyección encubierta y disimulada, de la propia vida y personalidad del autor" (p. 143), es decir que el lector debe encontrar elementos de autobiografismo dentro de la obra. La autoficción, en cambio, "se presenta como una novela, pero una novela que simula o aparenta ser autobiográfica con tanta transparencia y claridad que el lector puede sospechar que se trata de una pseudoautobiografía, o lo que es lo mismo, que aquel relato tiene "gato encerrado»" (Alberca, 2012, p. 145). Y aquí hay un gato enorme.

- ¿Tú crees que rompe la fórmula de la autobiografía? ¿Crees que ya no se trata del "relato retrospectivo en prosa que una persona real hace de su propia existencia, poniendo énfasis en su vida individual y, en particular, en la historia de su personalidad" (Lejeune, 1994, p. 50) sino de otra cosa?

- Se rompió el famoso pacto autobiográfico de Lejeune. Acuérdate que, según el francés, en cuanto firmas ese pacto, debes cumplir la famosa regla de veracidad, es decir, te comprometes a contar la verdad de los hechos, que se pueden cotejar fácilmente con un referente real. Si acaso se te ocurre escribir tu autobiografía, debes escribir "la verdad", si especulas o mientes sobre alguna persona, incluso sobre mí, puedes ser acusada jurídicamente por difamar a alguien. 
-Prometo mentir sobre ti.

- Mejor escribe la verdad. De pronto, por pesar, me publican la novela.

-Eso. Ahora que la vida privada está tan de moda, podremos reunir algunos fondos mintiendo sobre nuestra escandalosa vida de exestudiante y exprofesor.

-Buenísima idea: publiquemos nuestra falsa vida íntima para poder pagar las deudas -sonríe-. El tema es que, si sigues las reglas del pacto, tendrías que escribir con tu propio nombre. Cuando se escribe autobiografía, se da por hecho que la nominalidad de autor-narrador-personaje es la misma, es decir, no habría duda sobre tu identidad puesto que el pacto firma y asegura tal. Pero si decides volver nuestra historia más ficcional, pues el pacto autobiográfico desaparecerá para darle paso al pacto novelesco.

\section{—_La máxima de Coleridge}

"the willing suspension of disbelief" "?

-Aunque me gusta más como Eco (1992) redondea el concepto de pacto novelesco, cuando dice que al leer novelas el lector suscribe un pacto ficcional con el autor y acepta los hechos narrativos como si fueran verdaderos ${ }^{2}$ (p. 191).

-Muy aristotélico el asunto, ¿no? Ya no se trata de veracidad sino de verosimilitud. -Sí, y también se opone al pacto autobiográfico en que el autor, o la autora, difiere en identidad del narrador y/o del personaje, es decir, que no se puede identificar el autor con ninguno de estos, pues son entes diferentes entre sí.

— ¿Y cuál sería el pacto de la autoficción, si acaso existe eso? -Pues, es buena pregunta. Alberca (2007) habla de un pacto ambiguo: "Según se mire, la autoficción propone un pacto de ficción por la indicación genérica que preside el relato, o un pacto autobiográfico por la utilización del mismo nombre propio que el personaje toma del autor. Pero su simulación [...], puede ser doble y engañosa" (p. 129).

-Un pacto raro.

-Ambiguo.

— ¿Es la ambigüedad la que

crea el género?

-Puede ser. Fíjate, qué ironía, fue el mismo Lejeune (1992), años atrás, quien dio la primera puntada hacia la llamada autoficción. Al tratar de desarrollar cómo funciona cada uno de los roles de autor, personaje y narrador en un cuadro explicativo ${ }^{3}$ al que dedica una amplia descripción, deja unos "casos ciegos". El teórico, al intentar explicar tales casos, se pregunta: "El héroe de una novela ¿puede tener el mismo nombre que el autor? Nada impide que así sea y es tal vez una contradicción interna en la que podríamos deducir efectos interesantes. Pero, en la práctica, no se me ocurre

1 Arnaud Schmitt recuerda que el psicolingüista Richard G. Gerrig contradice a Coleridge y afirma que "de forma natural creemos en la realidad del mundo de la ficción; y el esfuerzo que realizamos no consiste en suspender nuestra incredulidad sino más bien en construirla («construction of disbelief»). En este sentido, [Gerrig] aventura que las únicas distinciones experienciales entre ficción y no ficción son aquellas que el lector hace el esfuerzo de construir (240)". Es una postura interesante y que, de cierta manera, nos acercaría más a la autoficción como un ejercicio ligado a la ficción y no necesariamente a la autobiografía.

2 Umberto Eco (1992). Los límites de la interpretación: 191.

3 Reproduzco el cuadro de Lejeune (1994) para intentar señalar con claridad aquellos que, en este caso, están en azul, y que para el crítico quedan ciegos:

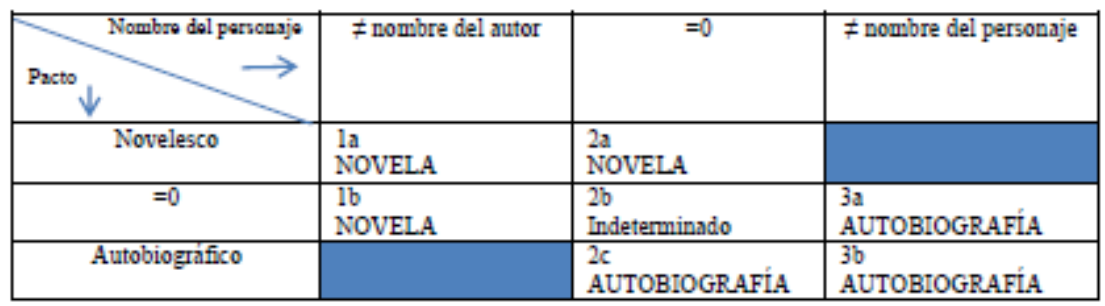


ningún ejemplo. Y si el caso se da, el lector tiene la impresión de que hay un error" (p. 70).

- Como que se quedó corto de miras - dice acomodándose las gafas, abanicándose con la revista porque el avión se ha quedado quieto no sé cuánto tiempo.

-Sí. Y esa limitación la aprovechó Doubrovsky al responder a esos "casos ciegos" con Fils (1977), un relato autobiográfico enmascarado en una novela, en donde el personaje-autor-narrador, "Serge Doubrovsky", se confiesa ante un psiquiatra.

-Muy francés el asunto.

-Ajá. En la contraportada de ese libro es donde el mismo autor utiliza el término "autoficción". Este diálogo entre literatura y teoría parece típico de la literatura contemporánea y no como en épocas pasadas que parecía haber incomunicación entre literatura y teoría (Diaconu, 2013, p. 35).

-Aunque, tengo la impresión que esa coincidencia nominal de autor-narrador-personaje no es tan reciente, ¿no, Casti? Mucho antes de la famosa muerte del autor de Barthes. Si mal no recuerdo, Borges escribió "El otro" en el setenta y cinco, es más, "Borges y yo", que tiene algo de eso es del ¿sesenta?

- Si nos ponemos más quisquillosos, hay un teórico, Vincent Colonna, que rastrea la autoficción en Luciano de Samósata, por allá en el siglo II, después de Cristo. Lo que pasa es que, en los últimos años, el tema de la autoficción cobró un auge interesante, tal vez es una especie de respuesta a los tiempos en los que vivimos.

- Tengo sed - dice buscando a la azafata. Giro las perillas del aire acondicionado para ventilarnos al máximo. — ¿Cuándo vamos a arrancar? -Fresco, Casti — toma mi mano en su mano. Luego, acalorada, la suelta - Me pregunto si el auge de las autoficciones también tienen que ver con los realities, con esa fórmula de los medios para atravesar la vida privada de la gente y volverla pública, como si todos fuéramos importantes.

- ¿No lo somos, Viole?

-No creo. Somos importantes mientras reportemos ganancias económicas a alguien, a una empresa. No sé... Tal vez mira por la ventanilla de nuevo- hay un ansia por la verdad más profunda, porque ya no se cree en nada. Leí un artículo sobre eso, sobre la insinceridad y cómo las novelas ahora trabajan eso. Espérame a ver si puedo verlo -rápidamente saca su teléfono móvil, busca en una página y lee en voz alta-: "La narrativa postmoderna ha topado con una reacción inesperada: después de que la sinceridad cayera en el desprestigio, por considerar que no era más que una especie de conveniencia personal. Hemos descubierto que la insinceridad nos molesta todavía más. Tuvimos ocasión de comprobar sus dañinas consecuencias en la política y en la economía, incluso en la historia” (Anna Caballé citada en artículo de Ruiz Padilla, en El País).

-Quizás. Y por eso, tal vez, la autoficción ha tenido tanto auge en las últimas décadas, una respuesta a ese juego.

-Puede ser. Pero, dime, ¿qué viene siendo la autoficción?

-Depende del autor. Alberca (2007) llama al subgénero de autoficción: "un híbrido elaborado a partir de elementos autobiográficos y ficticios" (p. 159). A pesar de ser registros incompatibles, autobiografía $\mathrm{y}$ ficción se funden $\mathrm{y}$ homogenizan para hacerse uno a través de una estrategia desconcertante y transgresora (Hernández, 2016, p. 80). Hay otra definición sencilla que dice que la autoficción es un "relato cuyo autor narrador y protagonista comparten la misma identidad nominal y cuyo intitulado genérico indica que se trata de una novela" (Lacarme citado en Pozuelo Yvancos, 2012, p. 156).

- Pero en esta novela ni la protagonista de la primera parte, ni la narradora de la segunda se llaman Margarita, Casti-me refuta con sus ojos brillantes tras las gafas-. El personaje se llama Catalina, de la narradora no sabemos su 
nombre, e incluso esa misma narradora dice que tiene una hermana que se llama Catalina (García Robayo, 2014, p. 174) ${ }^{4}$. -A ver -digo ahora mientras la pista de despegue al fin se mueve bajo nosotros-, no es la única definición. Hay otra más amplia, y ahí tal vez sí cabe. Un trío de estudiosas entiende la autoficción como

un subgénero literario $\mathrm{y}$ fílmico, que presenta una ficción [...] paradójica, [...] ambigua y lúdica, que en los textos literarios suele ser autodiegética. Incluye relatos situados entre los polos extremos de la verosimilitud biográfica y la inverosimilitud fantástica. El carácter (pseudo) confesional de un relato con identidad nominal y/u ontológica entre autor implícito, personaje y narrador es posible, pero no necesario, y varía según la intención de sentido. Un personaje ficticio -en la mayoría de los casos el protagonista autodiegético- se disfraza (continuamente o en grandes partes del texto) con el nombre o un derivado del autor real y/o con otras características similares (Toro, Luengo y Schlickers, 2010, p. 21).

Por supuesto que allí, sentado junto a Violeta, la cita me sale imprecisa, pero la parafraseo lo mejor que puedo.

\section{-Castillo-Rojo en su} mansplain time . $^{5}$.

- Tengo mis taras de profesor y de macho dominante.

- Tan bobo - ríe y me besa. -A ver, si seguimos esa definición, hay un carácter pseudoconfesional, de identidad ontológica que guarda una buena cantidad de características similares con la misma Margarita García, ¿no te parece? Si lo vemos detenidamente, entre los nombres Margarita y Catalina, hay cierta homofonía fonética, como señala el mismo Alberca. $\mathrm{Y}$ en dicha homofonía hay una "forma de afirmar parcial o veladamente una cierta identificación entre el autor y su personaje" (Alberca, 2007, p. 243), ¿no?

-Mmm... no sé. Como que

hilas muy fino.

-Viole, incluso se puede demostrar con otros elementos, muchos de ellos paratextuales, que hay coincidencias entre la autora, la niña y la narradora. En primer lugar, todas son cartageneras. Segundo, al igual que la narradora de la segunda parte, Margarita García escribió esta novela debido a la necesidad de entender y elaborar la muerte de su padre ${ }^{6}$; tercero, igual que esa misma narradora, García Robayo se fue a Argentina a labrarse una propia vida como escritora; cuarto, al igual que la niña de la primera parte, tenía once años cuando se firmó la constitución del 91. Se pueden rastrear varias coincidencias, tantas que es posible identificar la obra como autoficción.

-Pero esa ya es cosa tuya, de ti como lector. Si Margarita no dice que eso es autoficción, no creo que sea - refuta sonriendo, mientras se oye el mensaje del capitán avisando que, al fin, vamos a despegar-. ¡Ponte serio!

— ¡Es que no es nada serio! O bueno, eso mismo decía esta señora Darrieusecq sobre la autoficción, que era un género poco serio (pp. 65-82). Pero otro español, Ródenas de Moya (2014), argumenta

$4 \quad$ Todas las citas de la novela pertenecen a la edición: García Robayo, M. (2014). Lo que no aprendí. Barcelona: Malpaso Ediciones.

5 "Mansplain: (of a man) explain (something) to someone, typically a woman, in a manner regarded as condescending or patronizing". En Oxford Dictionaries.

$6 \quad$ En entrevista Margarita García dice: "Recuerdo que el momento cuando se me ocurrió escribir esta novela fue en el entierro de mi padre (...). Recuerdo mi interés y, al mismo tiempo, mi sorpresa cuando empecé a escuchar en el velorio, en la misa, en todos estos rituales que hay alrededor de la muerte de alguien, cómo mis hermanos, mis sobrinos, mi madre, la familia en general tenían recuerdos y versiones de lo que había sido mi padre tan distintas a mis propios recuerdos (...). Empecé a pensar que eso era un tema para escribir más adelante". 
que la ausencia de seriedad de la autoficción "responde más a la estrategia de hacer improcedente el principio de verificabilidad y sustituirlo por el de credulidad del lector" (p. 172), es decir que es el lector quien "debe procesar la narración como si se tratara de una ficción aun cuando tenga toda la apariencia de no serlo" (p. 172). Ródenas sentencia: la autoficción es "un modo de intensificar en el lector la sensación de que se enfrenta con los aspectos oscuros, perturbadores, conflictivos de la realidad" (p. 172). Por eso, como lector, me atrevo a acercarme a esta novela como autoficción.

- Hablando de aspectos perturbadores, dame la mano que ya vamos a despegar.

Después de sentir cómo aprieta mi mano, verla cerrar los ojos y persignarse, el avión deja el suelo y abandona la nube amarilla del Distrito Federal, al fin se vuelve a mirarme $y$, nerviosa, cierra los ojos.

-Quieres decir algo más

- dice al abrir los ojos y

señalarme unas montañas nevadas.

—CCómo sabes?

- Te empiezo a conocer.

-Pensaba en que hay un aspecto que me inquieta de esa autoficción. Creo que, en Lo que no aprendí, Margarita García Robayo está intentando crearse una identidad de escritora.
— ¿Cómo así? - dice Violeta. La ciudad nos deja, galopamos el aire.

-Es que, para ser escritor, como recuerda Premat (2009) al irrepetible Gombrowicz, "hay que, primero, fingirse escritor" (p. 12), porque así como el espíritu nace de la imitación del espíritu, "el escritor tiene que imitar al escritor para al final convertirse en escritor él mismo" (p. 12). Es decir, a fuerza de repetirse, el escritor o la escritora crea "[u]na autofiguración, un personaje que se crea, según una afirmación repetida $\mathrm{y}$ lúcida, en el intersticio entre el yo biográfico y el espacio de recepción de sus textos" (pp. 12-13). En la segunda parte de la novela, la narradora no solo necesita elaborar el duelo de su perdida, Viole, también necesita construirse como escritora, como lectora y quizás con esa conformación de entidades fantasmáticas, al fin se teje la autora Margarita García Robayo, para situarse en el mundo literario.

-A ver, futuro Ph.D., explíquese. Le doy oportunidad a su mansplaining, again.

-Mira, los protagonistas de autoficciones usualmente son los mismos escritores.

Esto quiere decir que no se trata de un simple ejercicio autobiográfico y ficcional de una persona $\mathrm{X}$ sino de alguien con un recorrido, con una expectativa y un posible interés de elaborarse un reconocimiento en el mundo literario. Es decir, este escritor o esta escritora necesita constituir una "ficción de autor" para entrar en aquel mundo. El concepto, explica Premat (2009), es "una invención de personajes de autor, que asumiendo la relatividad contemporánea, completa la ficción literaria, sirviéndole de marco y de marca a una inestabilidad y una incertidumbre estructurales" (p. 28).

- De nuevo me haces recordar a Borges, en "El otro". Cuando el Borges joven habla con el viejo, ahí sentados junto a una banca frente al río Charles, parece que ese viejo es el "relativo contemporáneo" del joven. El viejo completa la ficción literaria, y gracias a esta fantasía se convierte en marco y marca de inestabilidad.

—No lo había leído así —me alegra su inteligencia.

La azafata, al fin, nos deja dos Coca-colas y un par de sánduches.

- ¿Sabes qué es lo que me gusta más de la novela? —dice Violeta, sosteniendo la lata en la mano, con la mirada fija, concentrada en una idea-: La relación con el padre, en la primera parte. El personaje de la escritora de la segunda parte necesita adentrarse en su memoria, encontrar en su recuerdo una noción de su papá y establecer un vínculo más sólido con él, 
con lo que significó para ella en su infancia y lo que significa ahora, cuando ya no está hace una pausa para saborear la Coca-cola-. ¿Sabes? A mí también me gustaría aclarar ese vínculo enredado que tengo con mi papá: si es esa imagen difusa y triste de mi infancia, un tipo que nos quiere pero que no es feliz, o si es ese señor bonachón que se casó con otra mujer, diferente a mi mamá, y al que se le ve embobado con Samuel, mi hermanito. Pero ¿por qué no pudo embobarse con mi hermana y conmigo? ¿No éramos lo suficiente para su vida?

No sé qué decirle. También mis hijos tendrán problemas en su relación conmigo. Quizás cuando sean más grandes pueda explicarles por qué su madre y yo nos separamos. Sin embargo, esta fractura, esta división en su vida, será determinante. Solo espero que el tiempo lo permita. $\mathrm{O}$ que no sea tan traumático su crecimiento. Ojalá al menos pueda estar con ellos cuando me necesiten. Porque, no sé, si algo me pasa, digamos, si acaso este avión se cae, ¿se van a quedar con las explicaciones de su madre y la de su familia? ¿Será que lo único que recordarán de mí es que en vez de estar hoy en la casa con ellos, el vago ese, como diría su madre, regresaba de un viaje con la moza? Horrible. Si eso sucediera, tal vez mi hijo, de cuatro años, recordaría algo de mí. Mi hija de dos, en cambio, no recordaría nada. Yo sería una pieza blanca sin voz ni piel en su memoria. Un vacío.

—Casti — me dice Violeta con ojos soñolientos.

¿ ¿Um?

—QQué te pasa?

- Me hiciste pensar.

-No te apachurres. Más bien, dime, ¿cómo se construye la "ficción de autor"? — su voz me rescata.

-Pues, déjame recordar-tengo que tomarme un instante para apartar los ojos de mis hijos y pensar en conceptos-. Tiene que ver con lo que estábamos hablando. A ver, algo que he notado en varias autoficciones es que muchos de los autores, por ejemplo, Javier Cercas, Fernando Molano, VilaMatas, Guadalupe Nettel, entre muchos, establecen dos claves: la primera, una entidad fanstasmática que corresponde a una "ficción de lector" y la segunda, una entidad fantasmática que corresponde a una "ficción de escritor".

— ¿"Entidades fantasmáticas"?

-Es una idea del mismo Premat (2009). Dice el crítico argentino que en "el funcionamiento textual siempre estaría en juego otro ideal o un otro proyectivo, que permite la existencia del texto; esa otredad tiene que ver con entidades fantasmáticas ${ }^{7}$ del lector y del escritor" (p. 25). Sin embargo, no traduce esos conceptos. Para mí, esos dos elementos son la clave de la ficción de autor, es decir escribo en una servilleta-:

ficción de lector + ficción de escritor $=$ ficción de autor - ¿Y cómo lo ves en Lo que no aprendi? — pregunta Violeta.

-En la primera parte de la novela hay una ficción de lector, bueno, de lectora. Si bien Catalina se ha formado con obras como Los cinco y Nancy Drew, libros de "Julio Verne, los hermanos Grimm, Hans Christian Andersen, las fábulas de Esopo y Samaniego, y [libros] de Rafael Pombo y los poemas de Quevedo" (p. 113), solo cuando entra a la biblioteca de su padre a escondidas, y toma el libro Los siete principios, un libro esotérico, también conocido como El Kybalión,

El concepto recuerda, por otra parte, a las reflexiones que se hace Pozuelo Yvancos sobre el concepto figuración, alrededor de las figuraciones del yo, su perspectiva particular para analizar a la autoficción. Al reflexionar sobre el término, Yvancos recuerda que "figurar" se asimila con imaginar o fantasear, así como aparentar, suponer o fingir. Recuerda que en las definiciones de María Moliner, la estudiosa "tiene el acierto (como siempre) de remitir, entre otras, a la voz fantasma" (p. 162) y el término lo lleva a acercarse al termino griego phantasia. Según el crítico, la figuración del yo, consiste en que los escritores hacen uso de un yo figurado que "si bien posee virtualmente algunos rasgos de su autor, es un narrador que ha enfatizado precisamente los mecanismos irónicos [...] que marcan la distancia respecto de quien escribe, hasta convertir la voz personal en una voz fantaseada" (p. 168). Si bien Premat no señala la relación entre entidades fantasmáticas y fantasía, es verdad que busca comprender la representación del autor en la obra, ese "otro ideal". 
su rol como lectora cambia. $\mathrm{El}$ Kybalión, como sabes, es un libro de carácter metafísico que contiene principios herméticos y que se atribuye a "los tres iniciados", anónimos autores que, al parecer, tenían un vínculo con la masonería. Esa lectura determina, sin duda, su desarrollo como lectora. Por ejemplo -busco la cita en el libro-, aquí:

No era que no entendiera el libro, solo que decía cosas que nunca había oído. Por ejemplo, decía que la mente creaba realidades, o sea, que si uno pensaba una cosa con mucha intensidad esa cosa se hacía real. Se llama pensamiento creativo y no servía para lo material, lo que me parecía injusto. (p. 59).

Curiosamente, Aníbal tiene tatuada en la espalda una frase, también de El Kybalión, ite acuerdas?:

El tatuaje de Aníbal era una frase que le empezaba en el cuello y le terminaba en el huesito del ñango: «Suerte es el nombre que se le da a una ley no conocida». Le pregunté qué era eso.

— La frase de un sabio — dijo. (p. 63).

- ¿Ves? -Violeta me mira con ojos cansados-. Esa lectura, curiosa, inquieta, como menciona Piglia (2005) en el caso de Borges, "articula lo imaginario y lo real" (p. 27). Cuando la niña ve tatuada una frase del libro que está leyendo, esas ideas se vuelven carne, sabiduría, conocimiento. Es decir, siguiendo a Piglia (2005), "la lectura construye un espacio entre lo imaginario y lo real, desarma la clásica opinión entre ilusión y realidad" ( $p$. 27). Añadiría que esa condición de lectora curiosa le permite acercarse tanto al mundo del padre como al mundo, y al cuerpo, de Aníbal por afinidad intelectual.

-Tal vez sí - dice Violeta, bostezando.

-En la segunda parte, la ficción de lectora funciona así: como buena escritora, la narradora menciona a autores y citas que le ayudan a comprender su nueva situación. Cita un poema de Natalia Ginzburg (p. 161); un fragmento del "poeta infantil oscurísimo" (p. 171), como lo llama la narradora, Shel Silverstein, y de quien hay un epígrafe en la primera parte del libro. A la vez, habla de once escritores, sin nombrarlos, "que estaban escribiendo alguna novela sobre su padre o su madre" (p. 161); de un escritor famoso que "decía que hay que decir cosas necesarias" (p. 160), y menciona que "últimamente había estado leyendo novelas contemporáneas que consistían en esto de escribir dando cuenta de que se estaba escribiendo" (p. 171), y menciona dos libros recientes, de "Uno" y de "Dos", a quienes "les habían salido libros estupendos" (p. 171).

-Oye, Casti ¿no te parece súper interesante que la escritora quiera establecer sus vínculos con la lectura y la literatura pero oculta, sobre todo en lo último que citas, los nombres de esos autores, o los disfraza con los pronombres "Uno" y "Dos", diciéndonos sí, he leído, pero tal vez no es importante el nombre del autor?

- ¡Claro, Viole! Resulta este ocultamiento como un signo, una develación de su misma novela: oculto $\mathrm{mi}$ nombre, aunque sé que soy yo, la autora Margarita García Robayo, quien escribe y acaso protagoniza esta obra.

- ¿Y cómo funcionaría la "ficción de escritor", o mejor, de "escritora" en las dos partes? - dice y dobla la mesita al espaldar de la silla de enfrente.

-En la primera parte de la obra, es casi nula la relación con la escritura. Excepto, quizás, cuando la niña sale a montar en bicicleta y siempre deja una nota pegada en la nevera avisando que saldrá, lo que nos deja ver así es una mera relación práctica con la escritura.

-Espera, espera. No tan rápido -dice, acomodándoseSi pensamos que esa niña es la misma escritora de la segunda parte, ¿no tendría ya, en esa primera parte, el germen de la escritura? 
—AA qué te refieres?

-Es que cuando hablaste de la escritura y la infancia, me hiciste pensar en otro texto, en un libro que escribió Silvia Molloy, ¿te acuerdas?

-No, no he leído a Silvia Molloy.

- Te veo quedado, amor — es la primera vez que me dice amor. Los dos tenemos un momento de confusión. Nos miramos. La besó. Su boca, su lengua. Luego ella me besa. Sus dientes. Toco su cabello.

-Espera, espera -dice apartándose-. No quiero que se me olvide la idea.

-Olvídala.

-No -toma aire, parece buscar en su mente unas palabras-. Dice Molloy, si no estoy mal es cuando habla de las memorias de infancia de Norah Lange, ¿las has leído?

\section{-Tampoco.}

-No sé cómo puedes ser candidato a doctor sin haberla leído - ríe.

— No lo he leído todo repongo.

-Bueno, te adelanto solo la cita de Molloy, aunque las memorias de Lange son buenísimas. Mira, dice Silvia Molloy (1996) que en muchas de las memorias de infancia, en esa evocación, se autorreflexiona sobre los descubrimientos y experiencias del niño o de la niña, y a través de esa autorreflexión el sujeto trabaja su primera composición. Estos relatos de infancia deben considerarse, también, dentro del marco de la propia obra de ficción del autor o la autora. Tales textos (la cita que sigue apenas es esbozada en el avión, luego la reconstruiré y la transcribiré): "Sirven a menudo como pre-textos, como narrativas precursoras: el relato de niñez funciona aquí como matriz generadora de ficción a la vez que de vida" (p. 170).

— ¿Tú leíste la primera parte como memorias de infancia, Viole?

-No, claro que no. Pero si aceptamos tu tesis de que esto es una autoficción, y que en toda autoficción hay un componente autobiográfico, y si las memorias de infancia son una forma autobiográfica, es posible acercar Lo que no aprendi a tal género. Además, piensa que la segunda parte parece darle potencialidad a esa interpretación: cuando leemos a esa escritora hablando de su proceso de duelo, de los recuerdos de la casa, de la necesidad de escribir y contar su propia, acaso secreta, relación con su padre, parece darnos la posibilidad de ver el relato de Catalina como sus memorias de infancia.

-Puede ser, Violeta. Me gusta tu idea: hallar en ese relato, que recuerda a las memorias de infancia, la ficción de escritora de la primera parte.

—Sí, eso es. ¿Y, dime, cómo sería en la segunda?

—En la segunda parte, la ficción de escritora es la clave.
Acuérdate que la narradora empieza a señalar las fuentes básicas de donde salen sus escritos: de sus recuerdos, de la necesidad de elaborar el duelo, de las confusas imágenes que tiene de su padre...

—Y la parte de Bruno, el amigo gay - dice Violeta soltándose el cabello, hojea el libro.

-Esa parte es súper importante. Con Bruno, empieza a hacerse una idea de cómo construir una novela, una novela basada en sus memorias.

—Es esta — dice y lee en voz alta el diálogo:

Vos dame un nombre, que yo te doy la historia, me dijo. ¿Qué nombre? Cualquiera, un nombre que te guste. Alcé los hombros: no me gusta ningún nombre. Bufó. El nombre de una persona que te guste, que quieras mucho en la vida, insistió. Le dije: mi hermana Catalina es la persona que más me gusta en la vida. Y él:

Catalina tiene once años y cuatro hermanos mayores: tres niñas y un varón. Una de sus hermanas mayores tiene un novio que va a visitarla cada domingo.

Yo le digo: Catalina y su familia viven lejos, nadie va a visitarlos los domingos. (p. 174).

—Es un diálogo sobre imágenes para empezar una historia - 
le digo-, historia que, por supuesto, al ver el resultado, la primera parte, cambió; pero ese diálogo con un muchacho también escritor, artista con líos familiares, se vuelve un detonante importantísimo para poner en marcha la escritura, es el embrión.

-De acuerdo. Aunque el embrión parece estar compuesto por dos partes: las memorias de infancia, tal vez el elemento autobiográfico; y luego la ficción, creando ese nuevo bicho, ese híbrido.

-En esa encrucijada, en ese ir $\mathrm{y}$ venir entre el recuerdo y su día a día, entre la memoria y la invención, entre el allá y el acá, ocurre la estupenda aparición de la madre en Buenos Aires, ¿no? Esa visita empuja la necesidad de contar su versión de su padre, tan distinta a la de su mamá. ¿Te acuerdas de ese diálogo, después de que la madre regresa a Colombia? La escritora habla por teléfono con ella y tienen una breve discusión sobre los recuerdos. La mamá le dice "si no te gustan mis recuerdos, empieza a juntar los tuyos; y si tampoco te gustan ésos, cámbialos" ( $p$. 182). La narradora le dice, entre lágrimas, "yo no sé hacer eso". Y la mamá: "entonces aprende" (p. 182). Eso quiere decir, ahora lo entiendo, que lo que no aprendió, lo que le da título a la novela, fue eso, Viole: ella es incapaz de juntar sus recuerdos o cambiarlos. Sin embargo, y qué contradicción tan bacana, tenemos una novela en donde hay recuerdos transformados por la pluma de la ficción. Es decir, la escritora sí aprendió algo: aprendió, de la presencia de su padre, una lectura atenta; y de su ausencia, a escribir. Así se teje a una autora, o una ficción de autora.

-Oye, ¿y qué me dices de la narradora? - mi mira fijamente.

— ¿La narradora?

- Pues sí -intenta acomodarse en la silla-. Has hablado de la lectora y la escritora, pero ¿dónde dejas a la narradora? ¿No hay una ficción de narradora?

_Premat no habla de eso.

-Pues tú deberías

considerarlo. Si estamos

hablando de entidades

fantasmáticas, yo creo que la narradora también es una.

- Como por qué.

-Porque el narrador es, también, un artificio, es una creación hecha por un autor, o como decía Vargas Llosa (1997) es "un personaje inventado" (p. 53), una ficción que también hace parte de esa realidad literaria y que permite que el tejido del que hablas funcione, ¿no?

-Puede ser. ¿Pero te refieres a esa voz que, en este caso, narra en primera persona y que tanto en la primera como en la segunda parte se diferencia por un timbre diferente, por una sintaxis y tono diferentes?

-No me refiero solo al estilo de Margarita, que está muy bien pensado y que sin duda logra su efecto porque gracias al tono que recuerda una especie de diario de una niña, en la primera parte, y el de una especie de relato a modo confesional de la segunda, sin duda, la novela logra hacernos creer que esas narradoras son las mismas aunque a diferentes edades. Más bien, pienso en Benjamin (1991), cuando menciona que "[1]a muerte es la sanción de todo lo que el narrador puede referir y ella es quien le presta autoridad (p. 121)", porque si hay algo que le da peso a esta novela es, justamente, la muerte del padre. Si recuerdas, la novela se inicia con una supuesta muerte del padre, que está más bien en un estado cataléptico, y con esa imagen el relato empieza a abrirse en ese sentido. Es la muerte de ese hombre, ese mismo padre ausente, la que permite que la escritora deba reconstruir su vida como autora y narradora en ciernes en Argentina, ese fallecimiento es un impulso vital.

- ¿O sea que la entidad fantasmática de la narradora también surge gracias a, y a pesar de, la muerte?

-Sí. Una entidad fantasmática que se caracteriza por situarse en la primera persona de singular, y al hacerlo logra esa relación cercana con su familia, los seres que la rodean, y así crea el material básico, los 
hilos, para tejer la ficción de autora.

Guardamos silencio mientras atravesamos unas nubes.

- Me recuerdas a Sarah Kofman (2003), que guarda la pluma de su padre, el rabino llevado a Auschwitz, no solo como recuerdo sino como una especie de deber, de responsabilidad con la escritura.

- Creo que hay algo de eso dice bostezando.

- La muerte del padre que deja una huella y un duelo apenas revisado por la escritura, por la narración.

Otro silencio. Los motores del avión ondean sobre nuestro pensamiento.

-Tal vez -dice Violeta después de un largo bostezo-, Margarita necesitaba de esa distancia geográfica, irse, para poder hablar de su infancia, de su memoria. De pronto necesitaba alejarse, distanciarse, para poder crear su voz narrativa y llegar a una ficción de autora.

Lo último lo dice cerrando la ventanilla, oscureciendo el paisaje celeste y arropándose con su suéter aguamarina. Beso su frente. Cierro las perillas del aire acondicionado. Se recuesta sobre una almohada improvisada, mi saco enrollado, sequitalas gafas, y seva. Duerme incómoda, con el cuello torcido, con la boca entreabierta, nada que ver con la bella durmiente garcíamarquiana.

(García,
1992). La dejo dormir mientras tomo notas para el artículo. Para este artículo.

Bogotá nos recibe con su sabana y sus nubes turbulentas. Somos los últimos en dejar el avión, acaso porque sabemos que en tierra firme se quebrará la burbuja. Tomamos el mismo taxi. Observamos el tráfico de la calle 26 .

- Me pregunto si es la ausencia de mi padre lo que me impulsa a escribir - dice de pronto. — ¿Tú crees?

-Algo debe tener que ver. $\mathrm{Su}$ ausencia, sus recuerdos enemistados, su machismo, su horrible bigote, la fuerza de mi mamá para encargarse de dos niñas... Eso cala los huesos.

— ¿Y fue él el que te invitó a leer? ¿El que te acercó a la escritura?

-No. O bueno, quiero decir que no, aunque en el fondo sí nos llevó libros, nos acercó a la lectura.

¿Mis hijos dirán en unos años algo así? ¿Alguno de los dos escribirá por la ausencia que les he provocado, por lo que provocaré en ellos, o al contrario, se apartarán de los libros y la lectura porque no quieren mantener ninguna esencia de su padre? — ¿Y tú? ¿Tienes alguna ausencia que motive tu escritura?

Pienso en mis hijos.
—No lo sé.

Descendemos el puente de la Avenida Boyacá y al pasar bajo el puente de la Avenida Rojas, dice de pronto:

-Alguna vez deberíamos hacer nuestra propia ficción de autor.

- ¿Cómo?

- Irnos, emigrar, escribir.

Hacernos escritores fuera, en México o en Argentina.

— ¿Será necesario irse para ser escritores?

-De pronto a ti te sirve crear las ausencias. Y a mí me serviría estar lejos para recrearlas, quizás pueda escribir mis memorias de infancia y mezclarlas con ficción lejos de Colombia, quizás allá pueda descubrir mi voz narrativa, así como hizo Catalina, bueno, Margarita. Quizás lejos pueda estar junto a ti.

— ¿Y no necesitas de mi ausencia para escribir?

—Hoy no — dice recostándose en mi hombro.

Llegamos al edificio en que vive su mamá, bajamos las maletas. La besó. Prometo llamarla. Veo que el vigilante le ayuda con su equipaje y ella le sonríe, a pesar del cansancio. Tomo rumbo hacia la casa de la mamá de mis hijos. En el taxi, ojeo el libro que les he traído: Vamos a cazar un oso, una versión de Michael Rosen ilustrada por Helen Oxenbury. Quizás esto sea lo único por lo que me recuerden: por los libros, por las lecturas. Por las ficciones. 


\section{Referencias}

Alberca, M. (2007). El pacto ambiguo. De la novela autobiográfica a la autoficción. Madrid: Editorial Biblioteca Nueva.

Alberca, M. (2012). Las novelas del yo. En A. Casas, La autoficción. Reflexiones teóricas (pp. 123-149). Madrid: Arco Libros.

Barthes, R. (2016). La muerte del autor. Revista l

La letra del escriba, (51). Recuperado de www.teorialiterariawordpress.

Benjamin, W. (1991). El narrador. Para una crítica de la violencia y otros ensayos (pp. 111-134). Madrid: Taurus.

Borges, J. (2014a). El otro, Borges y yo. El hacedor (pp. 65-66). Barcelona: Debolsillo.

Borges, J. (2014b). Cuentos completos (pp. 427-434). Barcelona: Debolsillo.

Brewster, A. (1996). Fictocriticism: undisciplined writing. Writing teaching, teaching writing. The proceedings. First Annual Conference of The Association of University Writing Programs. 29-32. Sidney: University of Technology.

Calvino, I. (1996). Bajo el sol jaguar. En Bajo el sol jaguar (pp. 37-70). Barcelona: Túsquets.

Colonna, V. (2004). Autofiction \& autres mythomanies littéraires. Paris: Éditions Tristram.

Diaconu, D. (2013). Fernando Vallejo y la autoficción. Coordenadas de un nuevo género narrativo. Bogotá: Universidad Nacional de Colombia.

Eco, U. (1992). Los límites de la interpretación. Barcelona: Editorial Lumen.

García Robayo, M. (2014). Lo que no aprendí. Barcelona: Malpaso Ediciones.

Hernández, Peñaloza, A. A. (2016). El diario de un escritor en Encuentro en Saint-Nazaire de Ricardo Piglia. La Palabra, (28), 75-90.

Kofman, S. (2003). Calle Ordener, Calle Labat. Madrid: Cuatro Editores.

Lejeune, P. (1994) El pacto autobiográfico y otros estudios. Madrid: Megazul-Endymion.

Malpaso. (2013). Margarita García Robayo: Entrevistamos a la autora de Lo que no aprendí. Recuperado el 12 de octubre de 2016, de https:/www.youtube.com/watch?v=cTkLKeoS11M. 
Molloy, S. (1996). Acto de presencia: la escritura autobiográfica en Hispanoamérica. México: El Colegio de México- FCE.

Oxford Dictionaries. (2016). Recuperado de https://en.oxforddictionaries.com/definition/mansplain

Piglia, R. (2005). El último lector. Barcelona: Anagrama.

Pozuelo Yvancos, J. (2012). «Figuración del Yo» frente a autoficción. En A. Casas, La autoficción. Reflexiones teóricas (pp. 151-176). Madrid: Arco Libros.

Premat, J. (2009). Héroes sin atributos. México: FCE.

Ródenas de Moya, D. (2014). Reflexiones y verdades del yo en la novela española actual. En A. Casas, El yo fabulado. Nuevas aproximaciones críticas a la autoficción (pp. 169-190). Madrid / Frankfurt: Iberoamericana / Vervuert.

Rosen, M., \& Oxenbury, H. (2010). Vamos a cazar un oso. Caracas: Ekare.

Ruiz Padilla, J. (2017) La hora de la transparencia literaria. El País. Recuperado de www.elpais.com.

Schmitt, A. (2014). La autoficción y la poética cognitiva. En A. Casas (ed.), El yo fabulado. Nuevas aproximaciones críticas a la autoficción. Madrid / Frankfurt: Iberoamericana / Vervuert.

Toro, V., Schlickers, S., \& Luengo, A. (eds.) (2010). La obsesión del yo. La auto(r)ficción en la literatura española y latinoamericana. Madrid / Frankfurt: Iberoamericana / Vervuert. Tres iniciados, Los. El Kybalion. Bogotá: Ediciones Universales.

Vargas Llosa, M. (1997). Cartas a un joven novelista. Bogotá: Planeta. 